His zest for life was reflected in a wide variety of activities outside the workplace. At one stage he was president of his local synagogue and for many years he enjoyed walking the hills of the Peak District. He was an enthusiastic amateur baker (specialising in bagels) and a skilled rug maker. He was a devoted family man. Predeceased by his first wife Renee, he is survived by his second wife Marcia and his daughter Sharon. He died in 2011 aged 85.

Alec Jenner, Gethin Morgan

doi: $10.1192 / p b . b p .112 .039859$

\section{Dr Tomma Muhsin MBChB MRCPsych}

Formerly Consultant Psychiatrist for Older People and Lead Consultant for Older People and Adult Mental Health Services in North Lincolnshire, Rotherham, Doncaster and South Humber NHS Foundation Trust (RDaSH)

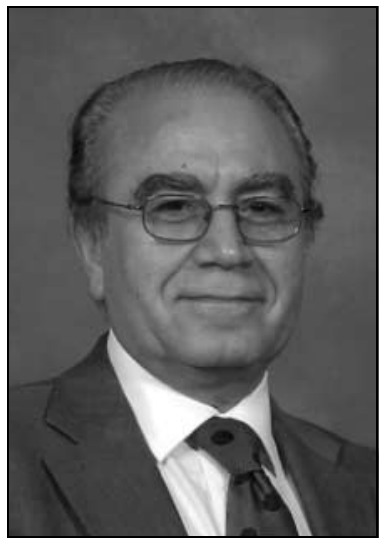

In recognition of Dr Tomma Muhsin's efforts in rebuilding healthcare services in Iraq, a postgraduate lecture hall in the new postgraduate centre at $\mathrm{Ibn}$ Rushd Teaching Hospital in Baghdad was named after him. He returned to his homeland several times with the purpose of improving provision for patients with mental illness; he also visited Kurdistan in the north and Basrah in the south. The lecture theatre in Baghdad was a tribute to his sterling efforts to a cause he cared about very deeply.

Tomma was born in 1950 in Baghdad and went to medical school there in 1968. Between studying and attending lectures he notably chaired an outlawed, left-wing students' union committee. He did his house jobs in Basrah and, after completing his military and rural services, he held a senior residency job at Ibn Rushd Hospital, the main acute psychiatric hospital in Baghdad. In 1981, he came to the UK to complete his training, but after finishing his psychiatric rotation at the Royal Free Hospital in London he decided to stay.

Tomma took great pride in his work for the National Health Service (NHS), both as a clinician and as a medical manager; he later became clinical director of adult and older peoples' mental health services in North Lincolnshire. His loyal service to the area was posthumously recognised by Rotherham Doncaster and South Humber NHS Foundation Trust, who dedicated a garden to him in the acute mental health unit in Scunthorpe.

Tomma was described by friends and colleagues as someone who was always fun to be with. He had a cheerful disposition, a relaxed and unrushed approach, and this made people feel at ease around him. Besides his work, Tomma had many other interests. He was a keen traveller and along with his wife he visited various parts of the world up until a couple of months before his death. He was interested in the history of the Middle East and Iraq in particular and was an avid reader of books and articles on the subject. He was proud of his Iraqi roots. He was a founder member of the Iraqi Mental Health Forum, a professional association of Iraqi expatriate mental health professionals in the UK. He was a past executive committee member and chair of this forum. He was also a member of the Iraqi Subcommittee of the Royal College of Psychiatrists.

Tomma's death has been a great loss to his many friends and colleagues. It has also been a great loss to mental health services in North Lincolnshire and to the mental health community both in the UK and in Iraq. His death will be felt most by his family. He died in November 2011 and is survived by his wife Amal, daughters Zeena and Huda, son Salam and grandson Zak.

Riadh Abed

doi: 10.1192/pb.bp.112.039792 